\title{
How effective is the European Union's Savings Tax Directive? Evidence from four EU Member States*
}

Thomas Rixen

Social Science Research Center Berlin (WZB), Reichpietschufer 50

10758 Berlin, Germany

E-Mail: <rixen@wzb.eu>

and

\section{Peter Schwarz}

Jacobs University Bremen

Campus Ring 1

28759 Bremen, Germany

E-Mail: <p.schwarz@jacobs-university.de>

* Forthcoming in the Journal of Common Market Studies. We received helpful comments and suggestions from Manuel Domes, Volker Heydt, Niels Johannesen and participants at the $66^{\text {th }}$ Annual Congress of the International Institute of Public Finance (IIPF) on “Tax Evasion, Tax Avoidance and Shadow Economy” in Uppsala, 2010. Mary Kelley-Bibra and Tobias Weise provided great technical and research assistance. We thank all of them. Peter Schwarz gratefully acknowledges financial support by the German Science Foundation (DFG) for the Collaborative Research Center 597 'Transformations of the State', Bremen. 


\title{
How Effective Is the European Union's Savings Tax Directive? Evidence from Four EU Member States
}

\begin{abstract}
This paper examines the strategies employed by individual investors to evade cross-border capital income taxation, and it evaluates the effectiveness of the EU Savings Tax Directive (STD). Using data for four European countries our results are as follows: First, individual investors adapted to the institutional changes implemented by the STD before it became effective in 2005. Second, we find that the strategy of reallocating assets from debt to equity products in the same country is more important than shifting portfolio capital out of cooperating countries into third countries. Third, countries opting for a retention tax did not experience an outflow of portfolio capital, whereas countries engaged in information exchange lost capital relative to third countries outside the scope of the STD. Finally, there is considerable heterogeneity across countries. While we find strong behavioral responses by French investors, we did not find evidence of cross border tax evasion by Italian investors, which may be explained by the absence of a national automatic reporting system on capital income in Italy. Overall, our findings show that the STD does not effectively prevent tax evasion and thus lend support to calls for tightening the directive.
\end{abstract}




\section{How effective is the European Union's Savings Tax Directive? Evidence from four EU Member States}

\section{Introduction}

All EU member states tax the worldwide income of their residents. Thus, irrespective of where the income is generated, capital income of natural persons is taxable at home (residence taxation). But economic integration and technological advances make it easy for citizens to conceal capital income from domestic tax authorities by depositing funds in foreign countries with low or zero tax rates, and by failing to report foreign source income. While the residence principle is applied de jure, it is often not enforced de facto. Effective enforcement of taxes on cross-border interest income requires the cooperation of the host country (where the funds are invested, also called the source country). Generally, two principles can be applied: (1) if the government of the host country provides information on the investor to the home country (where the investor resides, also called the residence country), then the home country can enforce its tax rules. The incentive to shift income to foreign countries for tax reasons is thus eliminated. (2) Tax evasion can also be addressed if taxes are withheld at source (in the host country).

Until recently, hardly any country used either of these two solutions, or even paid serious attention to matters of international tax enforcement. Over the last decade, however, international efforts to curb tax evasion have stepped up. Most prominently, the European Union (EU) and the Organisation for Economic Co-operation and Development (OECD) have undertaken projects against "harmful tax practices,” focusing in particular on information exchange (Commission, 1997; 2009; OECD, 1998; 2009; Radaelli and Kraemer, 2008; Radaelli, 2003). Of these initiatives, the one that is considered to be the most promising is the EU Savings Tax Directive (STD) (European Community, 2003). In 2003, after 35 years of unsuccessful attempts and protracted negotiations, a consensus on the taxation of foreign 
interest income was reached within the EU. With the STD, most EU member states and some third countries and dependent territories agreed to exchange information on the interest income of foreign citizens. The STD is seen as novel in the field of international tax enforcement, because it is the first binding legal instrument that provides for automatic and multilateral information exchange rather than on-request exchange, as foreseen under most bilateral tax treaties. Also, the only other two multilateral instruments which foresee information exchange, the recently renewed directive on mutual assistance in taxation (Council, 1977; 2010) and the convention on mutual administrative assistance in tax matters (OECD, 2003) only require on-request exchange. Many tax experts consider information exchange on request to be ineffective and have long argued for automatic exchange instead (Spencer, 2005; Palan et al., 2010, pp. 245-6). Under the STD, which has been in force since 1 July 2005, some countries have secured exceptions to the general rule of automatic information exchange. Instead, they withhold taxes at source for the benefit of the investors' home states without disclosing their identity, but are allowed to maintain $25 \%$ of the revenue for themselves. This upward scaling retention tax was $15 \%$ in 2005 ; it is currently $20 \%$ but will increase to 35\% by 2011.

While, because of its innovative features, it may be justified to regard the STD as a milestone in the fight against cross-border tax evasion, the directive nevertheless leaves significant loopholes for potential tax evaders. For one, at least until 2011, the retention tax remained comparatively low, and this provided a tax incentive for investors to leave funds abroad. Second, many countries outside the scope of the STD neither exchange information on interest income nor withhold taxes at source, so investors may be tempted to move funds to these third countries. Third, the STD applies to only one class of capital income - viz., interest - so it can be circumvented by restructuring portfolios from debt to equity (Schwarz, 2009; Commission, 2008a). Given these potential loopholes, it is our aim in this paper to determine how relevant they are empirically. We examine foreign capital flows before and after the implementation of the STD, and empirically assess how effective the STD has been 
in curbing international tax evasion. In particular, we are interested in gauging the relative importance of the three channels of evasion and the timing of taxpayers' adjustments.

Using bilateral data on portfolio capital for the EU member states France, Italy, Sweden, and Spain, our results show that owners of financial capital can exploit all three loopholes in the STD. But there are differences in the relative importance of these evasion channels. The strategy of reallocating assets from debt to equity is more relevant than shifting capital out of cooperating countries into non-participating third countries; and countries with a withholding tax experience a significantly smaller outflow of funds than those applying automatic information exchange. Also, we show that the process of asset reallocation was already occurring in 2003, the year in which the STD was ratified. This process drew to a halt by 2005, the year in which the STD came into force. Interestingly, we find no evidence of cross-border tax evasion by Italian investors. This may be due to the absence of an Italian national reporting system on capital income, so that Italian investors have not been pressed to move funds abroad.

Our empirical assessment is relevant for two reasons. First, the European Commission has pointed out weak spots in the STD and the extra revenue raised was disappointingly low (Commission, 2008a; see also Hemmelgarn and Nicodème, 2009). Currently, plans to strengthen the regime are discussed (Commission, 2008b). Knowledge about the practical weak spots of the current regime is helpful in designing the new rules. Our results suggest that the existing loopholes of the directive should be closed, since otherwise cross-border tax evasion cannot be curbed and the governments of EU member states will continue to lose tax revenues. Second, beyond the EU, international efforts to curb tax evasion have gained momentum in the wake of the recent global financial crisis. At the request of the G20 the OECD has issued so-called black and grey lists of tax havens; countries can only be removed from these lists when they fulfill the OECD's information exchange standard. But the OECD standard has been criticized for being too lax, because it provides for information exchange only on request, rather than for automatic exchange. Should we find that automatic 
information exchange is effective in the case of the STD this would lend support to calls for tightening the OECD standard (e.g. TJN, 2009).

The rest of the paper is structured as follows. In part I, we review the small body of empirical literature on international tax enforcement. Part II provides a discussion of the limitations of the STD and a brief history of its formation. In part III we present our data and the method of investigation. The results are presented in part IV and discussed in part V.

\section{Review of Empirical Studies on International Tax Enforcement}

The body of empirical literature on international cooperation against tax evasion is small. There are some political science studies analyzing the difficulties of establishing international tax cooperation, a significant part of which have dealt with the creation of the EU savings tax directive. These studies are relevant to our investigation because they can help us to understand why the STD exhibits certain loopholes. We return to these studies in the next section.

Another small body of literature directly related to our research question addresses cross-border tax cooperation against evasion. These papers ask, under what circumstances do countries have an incentive to engage in such cooperation (Keen and Ligthart, 2006)? Some authors suggest that the incentive to exchange information is weakened if the banking sector in a country is very profitable and if political decision makers weigh banks positively in their social welfare function (Huizinga and Nielsen, 2003). Closely related to this issue, Schwarz (2009) shows that high profitability of the financial sector enables countries to maximize revenues from corporate tax, and thus makes them unwilling to engage in information exchange. Another channel discouraging information exchange between fiscal authorities is related to spillover effects on the domestic labor market (Eggert and Kolmar, 2002). If an inflow of financial capital is indirectly associated with the creation of employment and wellpaid jobs, countries may be unwilling to exchange information; they thus become trapped in a prisoner's dilemma, in which cooperation is not achievable if political decision makers have a short time horizon. 
Four studies are relevant to the empirical part of our work on cross-border tax cooperation. Klautke and Weichenrieder (2010) analyze the effectiveness of the STD, pointing to the fact that the directive is not applicable to "grandfathered" bonds, i.e., bonds issued before 2001. If the STD were more stringent, then the pre-tax return of these taxprivileged bonds should be lower than that of other bonds. However, since both asset classes realize the same rate of return, Klautke and Weichenrieder conclude that the STD must leave other loopholes for tax evasion. They acknowledge, however, that this conclusion is justified only under the assumption that tax evaders are the marginal investors.

Before the STD went into effect, countries had the opportunity (which they continue to have today) to exchange information on the interest income of their citizens bilaterally, on request. Utilizing data from the Netherlands, Ligthart and Voget (2008) study the determinants of bilateral information exchange between the Netherlands and up to 81 host countries from 1992 to 2005. Their results indicate that information is exchanged more often, the higher the ratio of foreign assets and the higher the tax rate of the host country. Thus, the more heavily interest income is taxed, the more cooperative countries will be.

Third, Johannesen (2010) focuses on Switzerland and finds that the introduction of the retention tax under the STD led to a 40 \% drop of EU residents' non-bank deposits in the country. He obtains similar albeit lower behavioral responses for other offshore centers.

While Johannesen focuses on the retention tax, the study closest to our research design is that of Huizinga and Nicodème (2004) who treat information exchange as an exogenous variable. In their cross-sectional analysis for the year 1999 these authors show that bilateral information exchange between fiscal authorities does not depress capital flows between countries. Since their results do suggest that capital is more often located in foreign countries, the higher the income tax rate of the home country and the lower the withholding tax rate of the source country, tax considerations clearly play a role for depositing capital in foreign countries. Huizinga and Nicodème suggest that the insignificant coefficient of their information exchange dummy may reflect the fact that cross-border reporting of interest income was far from comprehensive at that time. The most important shortcoming is likely to 
be that bilateral agreements provide for information exchange on request only. The requesting state will have to present suitable initial evidence in order to receive the required information. Only in rare cases will tax administrations possess the required evidence. This, together with potential administrative difficulties such as language or different tax identification numbers, may explain why traditional bilateral information exchange is of limited effectiveness.

Given that the STD is viewed as an important step towards more effective tax cooperation but that we have only limited knowledge about its effectiveness, further research is called for to clarify the empirical question of whether (potential) tax evaders can exploit the directive’s loopholes. In a unique approach, we therefore consider alternative channels of tax evasion. The three loopholes we will assess are (1) placing money in countries which are not part of the STD, (2) switching to asset classes not covered by the STD, or (3) the comparatively low retention tax rates in those countries not participating in automatic information exchange. They are detailed in the following section.

\section{History and Limitations of the Savings Tax Directive}

The history of efforts to curb tax evasion and enforce a minimum level of personal capital taxation in the European Union dates back to the 1960s. Governments have conflicting interests on this issue, which made it difficult to achieve the required consensus to pass European legislation. Generally, the situation can be understood as an asymmetric prisoner's dilemma. While small countries and those with large financial and banking sectors can profit from capital tax competition, big countries favor regulation, if the rules are binding for all relevant countries (Dehejia and Genschel, 1999; Holzinger, 2005).

The first proposal of the European Commission from 1967 foresaw the introduction of national withholding taxes with a harmonized rate. The alternative solution of implementing information exchange was also considered, but it was withdrawn early on in the process due to concerns over bank secrecy rules. Since EU member states could not agree on a rate, the proposal was rejected. The Commission's second proposal was introduced in 1989. Instead of a harmonized rate, it foresaw merely a minimum withholding tax rate of $15 \%$ on foreign 
source interest income. This proposal was vetoed in the European Council because some member states rejected the idea of an EU minimum tax altogether, whereas others demanded the inclusion of dividends, or would have preferred a system of information exchange instead of the withholding tax solution. A third proposal was launched in 1998. The major shortcomings of its two predecessors were circumvented by allowing countries to choose between a retention tax and information exchange. This option can be interpreted as a side payment to countries opposed to the STD. The low withholding tax makes it possible for them to maintain bank secrecy and thus uphold their role as tax havens despite the fact that funds do not remain fully untaxed (for a discussion of the three proposals see Genschel, 2002, pp. 128-56).

The 1998 proposal formed the basis for the STD which was adopted by EU member states on 3 June 2003. ${ }^{1}$ The STD provides for a transitional period during which participating countries may choose between information exchange and a retention tax (European Community, 2003, Art. 10). ${ }^{2}$ If a country opts for information exchange, it must provide information about interest income automatically, at least yearly (Art. 9). At minimum, the transmitted information must contain the name of the beneficiary, his or her residence, and the amount of earned interest income (Art. 8). If a country opts for the withholding tax, the revenue is shared, with $25 \%$ remaining in the source country and $75 \%$ being transferred to the investor's country of residence (Art. 12). The original retention tax rate was 15\%; it has increased to $20 \%$ in 2008 and will be 35\% as of 1 January 2011. Table 1 provides an overview of the regimes chosen by different countries and dependent territories. Thus, the first reason why the STD may be ineffective is countries' opting for the retention tax over information exchange. Because the retention tax rate was low initially, it may not have curbed the incentive for investors to shift interest income into countries applying this solution.

\footnotetext{
${ }^{1}$ For a discussion of the negotiation process that led to this decision, see Uhl (2008, pp. 156-65).

${ }^{2}$ While the old member states (EU-15) could choose, new member states had to adopt information
} exchange. 
A crucial point in the negotiations surrounding the STD was to ensure that countries outside the EU participate in such an arrangement. It was feared that otherwise funds would simply migrate to third countries. Not only would member states continue to lose tax revenue, this would also endanger their banking sectors (Sharman, 2008). In order to avoid such displacement, the European Commission was authorized to negotiate with third countries and dependent territories about “equivalent measures.” Negotiations proved to be cumbersome, especially those with Switzerland which had a signaling function for other offshore centers. The EU therefore made Swiss cooperation on the STD a precondition for that country's accession to the Schengen Area. By the end of 2004 an agreement was reached, and Switzerland implemented the withholding option. Similar agreements were subsequently signed with Andorra, Monaco, San Marino, and Liechtenstein. Although the displacement argument was crucial to STD negotiations, the EU was not able to reach an agreement with the United States on proper equivalent measures, because the Bush administration was not interested in the issue (Sharman, 2008, pp. 1058-64). ${ }^{3}$ Other important third countries like Japan and offshore centers like Singapore or Hong Kong were also excluded (see table 1). Thus, the second potential loophole of the STD is that it can be circumvented by shifting funds to non-participating third countries.

Under the STD, interest income is defined as income from interest-bearing assets including bonds, zero bonds, government securities and other money market instruments, as well as income from investment funds. The latter is only part of the STD when more than $40 \%$ of the fund volume is invested in interest-bearing assets (European Community, 2003, Art. 6). The STD can be circumvented by reallocating funds so that they do not fall under the STD’s definition of interest. An investor has several possibilities to achieve this. One loophole, the third in our list, consists of so-called "grandfathered” bonds. These are bonds which were issued before 1 March 2001 with no re-issues after 28 February 2002. A fourth

${ }^{3}$ Holzinger (2005, pp. 504-5) speculates that the STD could be concluded despite the lack of agreement from important third countries, because it was felt that the OECD project was also progressing so that the displacement effect would be less severe. 
option is to shift to equity products which are not part of the STD's definition of interest

income. In the extreme the investor can replicate the payoff and risk profile of a bond through derivatives which are not covered by the STD. 
Table 1: STD Participating Countries and Dependent Territories

\begin{tabular}{|c|c|c|c|}
\hline Country & Regime & Country & Regime \\
\hline \multicolumn{2}{|l|}{ EU-15 } & \multicolumn{2}{|l|}{ Third Countries } \\
\hline Belgium & $\mathrm{WT}^{\mathrm{a}}$ & Andorra & WT \\
\hline Denmark & $\mathrm{IE}^{\mathrm{b}}$ & Liechtenstein & WT \\
\hline Germany & $\mathrm{IE}$ & Monaco & WT \\
\hline Finland & $\mathrm{IE}$ & San Marino & WT \\
\hline France & $\mathrm{IE}$ & Switzerland & WT \\
\hline Greece & $\mathrm{IE}$ & Anguilla & IE \\
\hline Great Britain & IE & Panama & Not included \\
\hline Ireland & $\mathrm{IE}$ & Singapore & Not included \\
\hline Italy & $\mathrm{IE}$ & Bahamas & Not included \\
\hline Luxembourg & WT & Panama & Not included \\
\hline Netherlands & $\mathrm{IE}$ & Bermuda & Not included \\
\hline Austria & WT & Barbados & Not included \\
\hline Portugal & $\mathrm{IE}$ & Hong Kong & Not included \\
\hline Sweden & $\mathrm{IE}$ & Montserrat & IE \\
\hline \multirow[t]{2}{*}{ Spain } & $\mathrm{IE}$ & Turks \& Caicos Island & WT \\
\hline & & Gibraltar & IE \\
\hline \multicolumn{2}{|c|}{ New EU-members } & USA & Not included \\
\hline Bulgaria & $\mathrm{IE}$ & Japan & Not included \\
\hline Cyprus & $\mathrm{IE}$ & & \\
\hline Czech Republic & $\mathrm{IE}$ & \multirow{2}{*}{\multicolumn{2}{|c|}{$\begin{array}{l}\text { Dependent } \\
\text { Territories }\end{array}$}} \\
\hline Estonia & IE & & \\
\hline Hungary & $\mathrm{IE}$ & Cayman Islands & IE \\
\hline Latvia & $\mathrm{IE}$ & Netherlands Antilles & WT \\
\hline Lithuania & $\mathrm{IE}$ & British Virgin Islands & WT \\
\hline Malta & $\mathrm{IE}$ & Guernsey & WT \\
\hline Poland & $\mathrm{IE}$ & Isle of Man & WT \\
\hline Romania & $\mathrm{IE}$ & Jersey & WT \\
\hline Slovakia & IE & Aruba & IE \\
\hline Slovenia & $\mathrm{IE}$ & & \\
\hline
\end{tabular}

a "WT" = Country applies the withholding or retention tax. In 2005, the rate was set at $15 \%$. It increased to $20 \%$ in 2008 , and by 2011 it will be set at $35 \%$.

b "IE” = Country participates in information exchange. 
The STD targets the foreign interest income of natural persons only. Thus a fifth channel of income tax evasion is the use of a legal person. This can be done either through a trust or a corporation. Because companies are subject to corporate tax, the relative advantage over realizing interest income as a natural person depends on the difference between the corporate and the retention tax. Since corporate taxes are low or zero in tax havens, interest income gained as a legal person will slip through this loophole in the STD.

In sum, the STD has five loopholes: (1) the - until 2011 - low retention tax rate. While this does not permit an investor to evade taxation altogether - he or she can save taxes in the host country relative to paying higher taxes at home - it may render the STD ineffective. In addition, there are four options which enable investors to fully circumvent the STD: (2) they can shift interest income to third countries which do not participate in the STD; (3) they can reallocate funds to grandfathered bonds or (4) equity products; or (5) they can invest funds in legal persons.

\section{Method and Data}

Our aim is to determine whether natural persons have been able to circumvent the STD. The data source for the dependent variables is the IMF Coordinated Portfolio Investment Income Survey (CPIS) (IMF, 2008). Starting in 1997, most developed and some developing countries have reported bilateral portfolio stock data to the IMF. ${ }^{4}$ In all cases we focus on the portfolio incomes of private households held abroad; banks, non-financial corporations and governments are excluded. Unfortunately, data in such a disaggregated form is not available

\footnotetext{
${ }^{4}$ Note that the IMF’s concept of residence does not necessarily coincide with nationality: rather, it refers to physical presence or legal residence. For example, the subsidiary of a German bank located in the Cayman Islands would be classified as a Cayman resident. In some cases assets may be held through base companies or financial institutions with no or only limited physical presence. In these cases residence is determined by the legal domicile of the firm. Indications for a legal domicile include the incorporation of a company in the respective territory, branches of a company incorporated abroad, and unincorporated enterprises with separate accounts. This means that the data should capture properly the reallocations we are interested in.
} 
for all countries; this leaves us with just four - namely, France, Italy, Sweden and Spain upon which our empirical analysis concentrates.

When we examine debt securities, we cannot distinguish between grandfathered bonds and debt instruments of which only the latter are covered by the directive. However, as Klautke and Weichenrieder (2010) have shown, the pre-tax return for these two asset classes does not differ. More importantly, our dataset also does not allow us to detect potential switches to corporate entities. Anecdotal evidence suggests that intermitting a legal person to circumvent the STD has been widely used. ${ }^{5}$ Accordingly, in its review of the STD, the Commission has singled out the inclusion of corporate entities in the scope of the directive as one of the two most pressing amendments - the other being the redefinition of income to include not only interest but also dividends (Commission, 2008b, pp.6-8). With our data we can test for the empirical relevance of debt-to-equity switching. However, one further limitation of the data is that financial derivatives are excluded from total portfolio capital, so we are unable to account for derivatives in our analysis of debt-to-equity switching. With these limitations borne in mind, we investigate the opportunities for financial capital owners residing in these four countries to shift capital to equity products or to third countries outside the scope of the STD.

We expect that either portfolio income in third countries rises after the implementation of the STD, or if the directive is technically ineffective, that fewer debt securities will be held in countries complying with the STD. Consider the case where investors with portfolio income from a country participating in the STD make dichotomous choices about the reallocation of their funds. Either they divert funds to third countries or they switch to equity

\footnotetext{
${ }^{5}$ See e.g.
}

http://www.shelteroffshore.com/index.php/offshore/more/eu_savings_tax directive_fails to_prevent_offshore_t ax_evasion (last accessed 13 December 2010), which reports that trust companies experienced rapid growth before the STD became effective. A trust was also used in the widely publicized 2008 Zumwinkel tax affair. The former CEO of the Deutsche Bundespost, Klaus Zumwinkel, was discovered to have hidden income in a Liechtensteiner trust. 
products in the same country. By switching to non-debt products in the same country, the impact of the STD on debt capital would be negative, leaving total portfolio income allocation across countries unaffected. The other case is diversion to third countries. As long as investors do not change the structure of their portfolios - i.e., the partition between debt and equity products - we would expect the impact of the STD on total portfolio income to be negative. At the same time the impact on debt capital should be insignificant. Clearly these thought experiments represent extreme cases. In reality investors may and probably do mix these strategies, which leaves us with the task of estimating the relative importance of these channels. For this reason we consider not only debt and total portfolio capital, but also the share of debt capital of the total assets invested. If investors prefer to switch to alternative asset classes rather than depositing capital in third countries, we would expect the share of debt to decrease.

We use a panel-data approach for the time span from 2001 to 2006 for bilateral pairs of countries. In the case of the residence country, our dataset is limited; for the source country we are able to analyze more than 130 cases. Our specification allows us to identify the effect of the STD on portfolio reallocation across countries and across asset classes. The following model constitutes the basis for our estimates:

$$
\mathrm{Y}_{\mathrm{ijt}}=\mathrm{X} \beta+\mu_{1} \mathrm{STD}+\alpha_{\mathrm{ij}}+\lambda_{\mathrm{t}}+\varepsilon_{\mathrm{ijt}}
$$

of which $Y$ is either the total portfolio capital or debt securities of the residents in country $i$ held in country $j$. Because we want to isolate the effect of the adoption of the STD, we use a fixed effects approach in all specifications. In so doing, we can control for variables that were found to be important in previous gravity equation approaches, but do not change over time like the distance between host and source country or whether, for instance, the countries share the same language. Whenever relevant, we also control for time effects because, beyond the introduction of the STD, alternative time-varying idiosyncratic shocks across countries could also be responsible for changes in the dependent variable; consider, for example, the global 
recession at the beginning of this decade. In the following section, we provide pooled results as well as for individual countries. All results are displayed with robust standard errors.

For some specifications we use additional control variables. First, portfolio capital held abroad by the citizens of the four countries in our study is a function of the deposit rate in the source country. The deposit rate is used because it captures (on a quite general level) differences in the pre-tax rate of return between countries. Data are from the IMF Financial Statistics (IMF, 2008). We expect a positive sign for debt capital. Second, we approximate institutional risk by applying a political stability indicator which measures the likelihood of conflicts or violence occurring in the source country. The indicator ranges from -2.5 to +2.5 ; higher scores indicate greater political stability. The data originates from the World Bank Governance Indicators (Kaufmann et al., 2008). The riskier the political climate, the less capital should be invested in a particular country; thus we expect a positive sign for debt capital and for total portfolio capital.

Our main interest is on $\mu$, the coefficient of our STD variable. To test our hypotheses we have constructed an index ranging from 0 to 2, where the country pair is coded zero if there is no information exchange and if the source country does not apply the retention tax. If taxes are withheld, the bilateral relationship is coded 1; if information is exchanged, the host country gets the highest score, 2 . We use an ordinal index because the incentive to reallocate funds under a withholding tax regime should be smaller than under an information exchange regime, since the withholding tax rate was only $15 \%$ for the time span under investigation. We also check to see whether our results are sensitive with respect to the coding procedure. As an alternative, we apply a test where tax cooperation is treated as a categorical variable. The results of this test are provided in section $\mathrm{V}$.

An important problem is that it is not clear when a reallocation of assets across classes and countries should be observable (Klautke and Weichenrieder, 2010). The final date should be 2005 when the STD came into force. However, it is likely that investors made changes to their portfolios earlier, because agreement on the STD had been reached in 2003. Following Weichenrieder and Klautke, we therefore decided to consider results for different cut-off 
points in the period ranging from 2003 to 2005; the treatment of the regime switch is between 2003 and 2005. Note, however, that even the early cut-off point still leaves us with two years, viz., 2001 and 2002, where cross-border tax cooperation was absent.

\section{Results}

Before turning to the results we first provide some descriptive statistics of our data. Table 2 provides the mean and standard deviation of the variables for the four countries. For example, French and Swedish individual investors on average hold roughly 400 million US dollars portfolio capital in each foreign country in our data set, whereas Italians hold about 2700 million US dollars (column 2). There are also some interesting differences with respect to the structure of assets. Whereas the debt share is more than $50 \%$ for Italians and more than $75 \%$ for Spaniards, French and Swedish investors hold less than 25\% and 10\%, respectively, in debt assets (column 1 relative to column 2). French and Swedish investors therefore hold a higher share of risky assets abroad. Although the sample sizes differ, the relative share of host countries covered by the STD is very similar across the four countries in our survey (column $5)$. 
Table 2: Descriptive Statistics ${ }^{6}$

\begin{tabular}{lccccc}
\hline & 1 & 2 & 3 & 4 & 5 \\
& Debt & Portfolio Capital & Stability & Deposit Rate & STD \\
\hline France & $93.7(312)$ & $419.2(1293)$ & $0.238(0.94)$ & $6.66(7.20)$ & 0.17 \\
Italy & $1423(4217)$ & $2717(15038)$ & $0.09(0.98)$ & $6.67(6.55)$ & 0.17 \\
Sweden & $38.6(118)$ & $407.8(2384)$ & $0.05(1.00)$ & $5.85(7.29)$ & 0.17 \\
Spain & $438.9(1773)$ & $567.4(2281)$ & $0.16(0.97)$ & $6.59(7.89)$ & 0.16 \\
\hline
\end{tabular}

Table 3 shows the results when analyzing total portfolio capital. All of our specifications include time effects, which were found to be significant. Our control variables do not seem to influence the amount of portfolio capital located abroad by residents of the four countries (column 4). This is perhaps because the deposit rate is too aggregated a measure to account for the heterogeneity across asset classes. The results are also modest for our tax cooperation indicator. Only if we apply an early starting point for tax planning, viz., 2003, the year in which the European Council adopted the STD, do we obtain a strong relationship between the treatment variable and the dependent variable. In sum, our results suggest that the reallocation process of portfolio income to third countries took place early and was all in all modest.

${ }^{6}$ Columns 1 and 2 show the average sum of debt and portfolio capital investors from the four countries hold in a reported foreign host country in millions of US dollars. The standard deviation is given in parentheses. Columns 3 and 4 show the average and standard deviation for political stability and deposit rates in the reported host countries. Column 5 indicates the share of reported host countries covered by the STD. 
Table 3: Determinants of Total Portfolio Capital

\begin{tabular}{|c|c|c|c|c|}
\hline & Portfolio (1) & Portfolio (2) & Portfolio (3) & Portfolio (4) \\
\hline STD 2005 & $\begin{array}{c}-0.050 \\
(-0.69)\end{array}$ & & & \\
\hline STD 2004 & & $\begin{array}{l}-0.062 \\
(-0.88)\end{array}$ & & \\
\hline STD 2003 & & & $\begin{array}{c}-0.175^{* *} \\
(-2.24)\end{array}$ & $\begin{array}{c}-0.168 * * \\
(-1.97)\end{array}$ \\
\hline Interest rate & & & & $\begin{array}{l}-0.003 \\
(-0.29)\end{array}$ \\
\hline Stability & & & & $\begin{array}{l}-0.271 \\
(-1.29)\end{array}$ \\
\hline $\mathrm{R}^{2}$ & 0.054 & 0.054 & 0.057 & 0.057 \\
\hline Time effects? & Yes & Yes & Yes & Yes \\
\hline Nobs & 1829 & 1829 & 1829 & 1423 \\
\hline
\end{tabular}

All estimations include a constant. $* * *=$ significant at $1 \%$, ** = significant at $5 \%$, and $*=$ significant at $10 \%$. $\mathrm{t}$ values are shown in parentheses.

Table 4 shows the results when we focus solely on debt capital. Compared to the analysis in table 3, we have fewer cases available here, because for some countries no disaggregated data on debt and equity capital was available. Again, as in the case of total portfolio capital, the relationship is only significant if 2003 is chosen as the cut-off point for the capital reallocation process. Compared to the coefficients in table 3, we see that the responsiveness of debt assets is somewhat greater than that of total portfolio capital. This is an initial indication that switching between different asset classes is more important as a channel of tax evasion than the reallocation of portfolio income between countries. In sum, the data in columns 1 to 4 suggest once again that investors adapted early to the STD; this reaction is more pronounced if we focus on debt capital.

Columns 5 and 6 of table 4 present a more thorough investigation of the relative impact of the STD on debt and total portfolio capital, because, as discussed above, focusing our analysis on the share of debt allows us to better differentiate between the third-country effect and asset-class switching. If switching to equity products is more important than placing 
money in third countries, then the share of debt should decline in countries participating in the STD. Estimates for the model are given with time effects (columns 5) and without them (column 6). As can be seen, the share of debt capital held by foreign private households has fallen in those countries abiding by the STD. This supports our contention. Although investors have used both options, shifting capital to third countries is less important than switching income between debt and equity products.

Table 4: Determinants of Portfolio Debt Capital

\begin{tabular}{lcccccc}
\hline & $\begin{array}{c}\text { Debt } \\
(1)\end{array}$ & $\begin{array}{c}\text { Debt } \\
(2)\end{array}$ & $\begin{array}{c}\text { Debt } \\
(3)\end{array}$ & $\begin{array}{c}\text { Debt } \\
(4)\end{array}$ & $\begin{array}{c}\text { Share Debt } \\
(5)\end{array}$ & $\begin{array}{c}\text { Share Debt } \\
(6)\end{array}$ \\
\hline STD 2005 & $\mathbf{- 0 . 0 2 9}$ & & & & & \\
& $\mathbf{( - 0 . 3 2 )}$ & & & & & \\
STD 200 & & $\mathbf{- 0 . 0 8 3}$ & & & & \\
& & $\mathbf{( - 0 . 9 0 )}$ & & & & \\
STD 2003 & & & $\mathbf{- 0 . 2 4 0 * *}$ & $\mathbf{- 0 . 2 0 4 *}$ & $\mathbf{- 0 . 0 9 4}$ & $\mathbf{- 0 . 1 4 8 * *}$ \\
& & & $\mathbf{( - 2 . 2 0 )}$ & $\mathbf{( - 1 . 7 1 )}$ & $\mathbf{( - 1 . 3 4 )}$ & $\mathbf{( - 2 . 1 8 )}$ \\
Interest rate & & & & 0.003 & & 0.001 \\
& & & & $(0.35)$ & & $(0.36)$ \\
Stability & & & & 0.000 & & 0.267 \\
R & & & & $(0.00)$ & & $(1.60)$ \\
Time effects & Yes & Yes & Yes & Yes & Yes & No \\
Nobs & 1242 & 1242 & 1242 & 982 & 1242 & 982 \\
\hline
\end{tabular}

All estimations include a constant. *** = significant at $1 \%, * *=$ significant at $5 \%$, and $*=$ significant at $10 \%$. $\mathrm{t}$ values are shown in parentheses.

\section{Robustness Analysis}

Up to now we have shown that tax cooperation across countries is accompanied by a reallocation of assets to equity products and, to a lesser extent, to third countries. However, important questions remain open, and we attempt to address them here. Specifically, we present two robustness tests, taking 2003 as the cut-off point in each case. 
So far we have assumed that countries exchanging information on interest income would bear the highest costs; these are followed by countries applying the retention tax. Because the ordinal scale of our indicator may be too strong an assumption, we re-calculate the models presented in the previous section by treating the cases "neither withholding tax nor automatic information exchange," "withholding tax," and "(automatic) information exchange” as dichotomous variables. This approach has the advantage that it could help us to gauge the relative effectiveness of withholding taxes compared to information exchange. Table 5 presents the results when we treat the different regimes as categorical variables. Note that the reference category is "no cooperation in tax matters"; the coefficients must therefore be read with respect to the reference category. Columns 1 to 4 provide the results for (absolute) debt and the share of debt capital; columns 5 and 6 focus on total portfolio capital. Although it may be theoretically justifiable, there is little empirical reason to believe that the different regimes can be ordered. Thus our implicit assumption that countries applying a withholding tax must fear (albeit to a lesser extent than those engaging in information exchange) an outflow of portfolio capital from private households is incorrect. Regardless of whether we focus on debt or total portfolio capital, countries opting for a withholding tax are just as attractive to foreign investors as countries which do not provide any assistance in the international taxation of cross-border interest income. 
Table 5: Withholding Taxation versus Information Exchange

\begin{tabular}{lcccccc}
\hline & $\begin{array}{c}\text { Debt } \\
(1)\end{array}$ & $\begin{array}{c}\text { Debt } \\
(2)\end{array}$ & $\begin{array}{c}\text { Share Debt } \\
(3)\end{array}$ & $\begin{array}{c}\text { Share Debt } \\
(4)\end{array}$ & $\begin{array}{c}\text { Portfolio } \\
(5)\end{array}$ & $\begin{array}{c}\text { Portfolio } \\
(6)\end{array}$ \\
\hline Withholding & $\mathbf{0 . 1 0 9}$ & $\mathbf{0 . 0 5 1}$ & $\mathbf{- 0 . 2 1 3}$ & $\mathbf{- 0 . 0 6 5}$ & $\mathbf{0 . 2 1 4}$ & $\mathbf{- 0 . 0 8 3}$ \\
tax & $\mathbf{( 0 . 4 2 )}$ & $\mathbf{( 0 . 0 9 )}$ & $\mathbf{( - 1 . 3 9 )}$ & $\mathbf{( - 0 . 3 8 )}$ & $\mathbf{( 0 . 8 6 )}$ & $\mathbf{( - 0 . 3 7 )}$ \\
Information & $\mathbf{- 0 . 5 1 7 * *}$ & $\mathbf{- 0 . 4 1 7 *}$ & $\mathbf{- 0 . 3 4 1 * * *}$ & $\mathbf{- 0 . 1 9 1}$ & $\mathbf{- 0 . 4 0 8 * * *}$ & $\mathbf{- 0 . 3 3 9 * *}$ \\
exchange & $\mathbf{( - 2 . 3 3 )}$ & $\mathbf{( - 1 . 7 3 )}$ & $\mathbf{( - 2 . 9 3 )}$ & $\mathbf{( - 1 . 5 5 )}$ & $\mathbf{( - 2 . 6 4 )}$ & $\mathbf{( - 1 . 9 8 )}$ \\
Interest rate & & 0.003 & & & & -0.003 \\
& & $(0.33)$ & & & & $(-0.28)$ \\
Stability & & 0.004 & & & & -0.270 \\
R & & $(0.01)$ & & & & $(-1.38)$ \\
Time effects? & Yes & Yes & No & Yes & Yes & Yes \\
Nobs & 1242 & 982 & 1242 & 1242 & 1829 & 1423 \\
\hline
\end{tabular}

All estimations include a constant. $* * *=$ significant at $1 \%$, ** = significant at $5 \%$, and $*=$ significant at $10 \%$. $\mathrm{t}$ values are shown in parentheses.

There may be several reasons for these interesting and at first glance surprising results. First the withholding tax will remain low up to 2011, and may not deter households from depositing capital income in foreign countries. Second, in the preceding section we showed that the switch to equity products appears to be more important than reallocation of capital to third countries. This same result reappears here: for the share of debt capital we obtain a weakly significant negative relationship for withholding countries (table 5, column 3). Finally, on the macro level there are different counteracting effects, which could explain the insignificant coefficients for countries opting for the retention tax. Even if some tax evaders are deterred by withholding tax rates of $15 \%$ or more and move their money to third countries, under such a regime, a country can attract additional funds from investors who may have previously placed their money in countries now exchanging information. Thus the outflow of capital by one group of evaders may be counterbalanced by an inflow of capital from countries that opted for information exchange. We find some indirect evidence for this hypothesis when we consider the coefficient of information exchange. Countries exchanging information with the four countries in our study experienced a large outflow of portfolio 
capital and an even stronger decline in debt capital (see table 5, column 2). Taken together these results suggest that, first of all, the withholding tax has so far not restricted tax evasion. Second, those countries favoring more tax cooperation (information exchanging countries) have difficulties in obtaining the tax revenues properly due from capital income. This disadvantage of information exchanging countries could peter out from 2011 on, when the withholding tax will be $35 \%$.

A further concern about the validity of our results is that they refer to the overall effect of tax cooperation. Up to now we have considered the impact of the STD on all countries, leaving the possible heterogeneity the STD may potentially exhibit in the country intercepts. Since different institutional features of the countries under consideration and different incentive mechanisms for tax evasion could result in different impacts across countries, we provide some results when each country is treated separately. Just as we did in the full country sample, we use fixed time and country effects. The results for the control variables generally proved to be insignificant and are not reported here. ${ }^{7}$

Turning now to table 6 , we see that there are some striking similarities but also important differences across countries. The coefficients for all variables exhibit considerable heterogeneity across the four countries. These differences in responsiveness can reflect differences in the propensity to place capital income abroad or they could stem from the fact that the host country sample is different for each of the four home countries. For example the number of host countries of Swedish and Spanish investors is smaller than of French and Italian investors. In the case of portfolio capital, the responsiveness of investors investing in information exchanging countries ranges between -0.2 (Italian investors) and -1.0 (Spanish and French investors).

\footnotetext{
${ }^{7}$ If we introduce the political stability indicator and the deposit rate we lose cases, because data is unavailable for some host countries. Since the coefficients of our variables of interest remain similar, we report only the results of the parsimonious model. Results including the deposit rate and the political instability indicator will be provided by the authors upon request.
} 
Table 6: Disaggregated Results for Individual Countries

\begin{tabular}{lcccccccc}
\hline & \multicolumn{2}{c}{ France } & \multicolumn{2}{c}{ Italy } & \multicolumn{2}{c}{ Sweden } & \multicolumn{2}{c}{ Spain } \\
& Debt & Portfolio & Debt & Portfolio & Debt & Portfolio & Debt & Portfolio \\
\hline Withholding & $\mathbf{0 . 1 6 0}$ & $\mathbf{0 . 3 7 0}$ & $\mathbf{- 0 . 0 2 3}$ & $\mathbf{0 . 6 2 8}$ & $\mathbf{- 1 . 1 9 4}$ & $\mathbf{- 0 . 0 7 3}$ & $\mathbf{- 0 . 0 0 6}$ & $\mathbf{- 0 . 7 3 9 *}$ \\
tax & $\mathbf{( 0 . 4 0 )}$ & $\mathbf{( 0 . 9 8 )}$ & $\mathbf{( - 0 . 0 7 )}$ & $\mathbf{( 1 . 1 8 )}$ & $\mathbf{( - 1 . 2 5 )}$ & $\mathbf{( - 0 . 2 1 )}$ & $\mathbf{( - 0 . 0 1 )}$ & $\mathbf{( - 1 . 7 2 )}$ \\
Information & $\mathbf{- 1 . 9 8 4 * * *}$ & $\mathbf{- 0 . 9 1 0 * * *}$ & $\mathbf{0 . 3 3 3}$ & $\mathbf{- 0 . 1 8 7}$ & $\mathbf{- 0 . 9 7 3}$ & $\mathbf{- 0 . 3 1 5}$ & $\mathbf{- 1 . 0 7 8}$ & $\mathbf{- 0 . 9 6 1 * * *}$ \\
exchange & $\mathbf{( - 4 . 8 3 )}$ & $\mathbf{( - 2 . 7 5 )}$ & $\mathbf{( 1 . 1 1 )}$ & $\mathbf{( - 0 . 6 6 )}$ & $\mathbf{( - 1 . 5 5 )}$ & $\mathbf{( - 1 . 1 5 )}$ & $\mathbf{( - 1 . 9 1 )}$ & $\mathbf{( - 3 . 0 1 )}$ \\
$\mathrm{R}^{2}$ & 0.200 & 0.141 & 0.021 & 0.056 & 0.391 & 0.316 & 0.196 & 0.230 \\
Time effects? & Yes & Yes & Yes & Yes & Yes & Yes & Yes & Yes \\
Nobs & 393 & 531 & 497 & 625 & 132 & 336 & 220 & 337 \\
\hline
\end{tabular}

All estimations include a constant. ${ }^{* *}=$ significant at $1 \%$, ${ }^{*}=$ significant at $5 \%$, and $*=$ significant at $10 \%$.

$\mathrm{t}$ values are shown in parentheses. 
But the four countries also exhibit similarities. First, except for Swedish investors, the withholding tax regime is not accompanied with an outflow of debt capital. This is in line with our pooled analysis. Second, in all four countries debt instruments are more responsive than total portfolio income. This difference is strongest for French investors. Third, all countries providing these four countries with taxpayer information experienced a reallocation of capital from investors of these countries - Italian investors being the sole and notable exception in this case.

French investors were more responsive to the implementation of the STD than Spanish investors, and Spanish more so than Swedish. What we can conclude is that the introduction of the STD was accompanied by behavioral responses of individuals from those three countries. Italy remains an exception: here we find no effect. Tax evasion theory suggests different reasons for this result. It may be explained by different tax cultures (Feld and Frey, 2002), the probability of detection, or the severity of punishment for tax evasion (Allingham and Sandmo, 1972), or differences in institutional frameworks. With respect to the probability of detection, it is possible that evading taxes in the home country and cross-border tax evasion are substitutable: the latter is strengthened whenever tax evasion at home is difficult. With respect to capital income taxation, it is especially important that a national information reporting system exists, under which banks automatically transmit information on accounts and deposits to tax administrations; otherwise investors might be tempted to conceal their incomes at home because of the low detection costs there. Of the four countries we analyzed Italy was the only without an automatic national reporting system (Huizinga and Nicodème, 2004). ${ }^{8}$ This may explain the results for the Italian case.

${ }^{8}$ In 2005 Italy did at least introduce the possibility for tax authorities to request information on taxpayers' accounts (OECD, 2007, p. 23). This is, however, far less effective to prevent evasion than automatic reporting. 


\section{Conclusion}

This paper dealt with tax avoidance strategies by individual investors in cross-border capital income taxation, and it evaluated the effectiveness of the European Union's Savings Tax Directive. Using data for four European countries, our results are thus: First, we found significant behavioral responses after international tax enforcement had been strengthened. Second, our results strongly suggest that individual investors adapted early to the institutional changes forced by the STD (in 2003 when agreement was reached). Third, given this result, the effectiveness of the STD is limited, but there is considerable heterogeneity across countries. French investors in particular, but also Spanish and Swedish capital owners seem to exploit the loopholes in the STD. Fourth, the results show that a reallocation of assets in the same country by switching from debt to equity is more common than shifting portfolio capital out of cooperating countries into third countries.

All in all, this makes a good case for closing these loopholes by integrating equity products into the directive. While our findings indicate that the fear of portfolio income fleeing en mass to non-European third countries is exaggerated, the inclusion of leading offshore centers in the revised STD is a useful strategy per se; it encourages already participating offshore centers to agree to an extension and tightening of the directive. Moreover, since the different evasion channels are in a substitutive relationship, closing one could implicate that the others become more attractive. Ideally, all loopholes should therefore be closed at the same time.

Finally, we have shown that countries applying withholding taxes did not initially lose portfolio capital. It is likely that the rate increase to $35 \%$ in 2011, which is higher than the tax rate on interest income in many member states, will change this situation. Nevertheless, it seems preferable to make automatic information exchange compulsory for all countries. This would prove that Europe is serious about putting an end to bank secrecy. The recent renewal of the directive on mutual assistance in tax matters (Council, 2010), under which current retention tax countries for the first time agreed to exchange tax relevant information may be seen as a hopeful sign. For capital income, the agreement on mutual assistance provides for 
information exchange on request only. ${ }^{9}$ Since it is thus limited in its effectiveness, the automatic exchange under the STD would be the logical next step in the fight against bank secrecy.

Though we have taken the first step in analyzing the effects of cross-border tax cooperation, many interesting questions remain open. With more data, one might be able to better address the matter of observable differences in country elasticity. Also, because the focus of our study was restricted to tax evasion by switching to different asset classes or to third countries, expanding the analysis to include legal persons would seem to be a logical and promising next step for future research.

\section{References}

Allingham, M.G. and Sandmo, A. (1972) 'Income Tax Evasion: A Theoretical Analysis'. Journal of Public Economics, Vol. 1, No. 3-4, pp. 323-338.

Commission of the European Communities (1997) 'A Package to Tackle Harmful Tax Competition in the European Union'. Communication, COM(97)564final, 5 November, Brussels.

Commission of the European Communities (2008a) 'Proposal for a Council Directive amending Council Directive 2003/48/EC on Taxation of Savings Income in the form of

\footnotetext{
${ }^{9}$ In fact, finance ministers fashioned a compromise according to which the renewed directive foresees automatic information exchange for certain types of income from 2015 on, namely income from employment, directors' fees, certain life insurance products, pensions, and ownership of and income from immovable property. But dividends, capital gains and royalties are excluded at least until 2017, when the effects of automatic exchange will be evaluated (See Council, 2010).
} 
Interest Payments'. Commission Staff Working Document. SEC(2008)2767. Brussels, 13 November 2008.

Commission of the European Communities (2008b) 'Proposal for a Council Directive amending Directive 2003/48/EC on Taxation of Savings Income in the form of Interest Payments'. COM(2008)727 final, 13 November 2008.

Commission of the European Communities (2009) 'Promoting Good Governance in Tax Matters'. Communication, COM(2009)201final, 28 April 2009, Brussels.

Council of the European Communities (1977) 'Council Directive of 19 December 1977 concerning Mutual Assistance by the Competent Authorities of the Member States in the Field of Direct Taxation'. 77/799/EEC, 19 December 1977.

Council of the European Communities (2010) 'Combating Tax Fraud: Agreement on Strengthened Mutual Assistance and the Exchange of Information'. Press Release 15094/10, 7 December 2010.

Dehejia, V.H. and Genschel, P. (1999) 'Tax Competition in the European Union'. Politics \& Society, Vol. 27, No. 3, pp. 403-430.

Eggert, W. and Kolmar, M. (2002) 'Residence-Based Capital Taxation in a Small OpenEconomy: Why Information is Voluntarily Exchanged and Why it is not'. International Tax and Public Finance, Vol. 9, No. 4, pp. 465-482.

European Community (2003) 'Council Directive 2003/48/EC of 3 June 2003 on taxation of savings income in the form of interest payments'. Official Journal, Vol. L 157, pp. 3848.

Feld, L.P. and Frey, B.S. (2002) 'Trust breeds Trust: How Taxpayers are treated'. Economics of Governance, Vol. 3, No. 2, pp. 87-99. 
Genschel, P. (2002) Steuerharmonisierung und Steuerwettbewerb in der Europäischen Union (Frankfurt a.M.: Campus).

Hemmelgarn, T. and Nicodème, G. (2009) 'Tax Co-ordination in Europe: Assessing the First Years of the EU Savings Tax Directive'. European Commission Taxation Papers No. 18. Holzinger, K. (2005) 'Tax Competition and Tax Cooperation in the EU. The Case of Savings Taxation'. Rationality and Society, Vol. 17, No. 4, pp. 475-510.

Huizinga, H. and Nielsen, S.B. (2003) 'Withholding Taxes or Information Exchange: The Taxation of International Interest Flows'. Journal of Public Economics, Vol. 87, No. 1, pp. 39-72.

Huizinga, H. and Nicodème, G. (2004) 'Are International Deposits tax-driven?'. Journal of Public Economics, Vol. 88, No. 6, pp. 1093-1118.

International Monetary Fund (IMF) (2008) 'International Financial Statistics'. CD-Rom.

Johannesen, N. (2010) 'Tax Evasion and Swiss Bank Deposits'. Manuscript, Department of Economics, University of Copenhagen.

Kaufmann, D./Kraay, A. and Mastruzzi, M. (2008) 'Governance Matters VII: Aggregate and Individual Governance Indicators 1996-2007'. World Bank Policy Research Working Paper No. 4654.

Keen, M. and Ligthart, J.E. (2006) 'Information Sharing and International Taxation: A Primer'. International Tax and Public Finance, Vol. 13, No. 1, pp. 81-110.

Klautke, T. and Weichenrieder, A.J. (2010) 'Interest Income Tax Evasion, the EU Savings Directive, and Capital Market Effects'. Fiscal Studies, Vol. 31, No. 1, pp. 151-170. Ligthart, J.E. and Voget, J. (2008) 'The Determinants of Cross-Border Tax Information Sharing: A Panel Data Analysis'. Mimeo. 
OECD (1998) Harmful Tax Competition. An Emerging Global Issue (Paris: OECD).

OECD (2003) Joint Council of Europe/OECD Convention on Mutual Administrative Assistance in Tax Matters. http://www.oecd.org/dataoecd/11/29/2499078.pdf, last accessed 13 December 2010.

OECD (2007) Improving Access to Bank Information for Tax Purposes. The 2007 Progress Report (Paris: OECD).

OECD (2009) Tax Co-operation. Towards a Level Playing Field. 2009 Assessment by the Global Forum on Transparency and Exchange of Information (Paris: OECD).

Palan, R./Murphy, R. and Chavagneux, C. (2010) Tax Havens. How Globalization Really Works (Ithaca: Cornell University Press).

Radaelli, C.M. (2003) 'The Code of Conduct against Harmful Tax Competition: Open Method of Co-ordination in Disguise?'. Public Administration, Vol. 81, No. 3, pp. 513-531.

Radaelli, C.M. and Kraemer, U.S. (2008) 'Governance Areas in EU Direct Tax Policy'. Journal of Common Market Studies, Vol. 46, No. 2, pp. 315-336.

Schwarz, P. (2009) 'Why are Countries Reluctant to Exchange Information on Interest Income? Participation in and Effectiveness of the EU Savings Tax Directive'. International Review of Law and Economics, Vol. 29, No. 2, pp. 97-105.

Sharman, J.C. (2008) 'Regional Deals and the Global Imperative: The External Dimension of the European Union Savings Tax Directive'. Journal of Common Market Studies, Vol. 46, No. 5, pp. 1049-1069.

Spencer, D. (2005) 'Tax Information Exchange and Bank Secrecy'. Journal of International Taxation, Vol. 16, No. 3, pp. 22-30. 
Tax Justice Network (TJN) (2009) 'TJN writes to the G20'. April 30, 2009. http://taxjustice.blogspot.com/2009/04/tjn.html, last accessed 9 March 2010.

Uhl, S. (2008) Die Transformation nationaler Steuersysteme in der Europäischen Union (Frankfurt a.M.: Campus). 